\title{
MENINGKATKAN KETERAMPILAN INTERPERSONAL MELALUI KONSELING TEMAN SEBAYA SEKOLAH MENENGAH ATAS NEGERI 1 SEGEDONG
}

\author{
Hendrik $^{1)}$, Toni Elmansyah ${ }^{2)}$ \\ 1) IKIP PGRI Pontianak, Pontianak, Indonesia \\ E-mail: iklilzaki@gmail.com \\ ${ }^{2)}$ IKIP PGRI Pontianak, Pontianak, Indonesia \\ E-mail: merah.semangka@gmail.com
}

\begin{abstract}
Abstrak. Tujuan penelitian ini adalah 1) mengetahui pelaksanaan konseling teman sebaya, 2) mengetahui keefektifan konseling teman sebaya meningkatkan keterampilan interpersonal siswa. Metode penelitian ini adalah penelitian tindakan bimbingan dan konseling. Subjek uji coba terbatas terdiri dari 34 siswa. Hasil penelitian menunjukkan bahwa konseling teman sebaya dapat meningkatkan keterampilan interpersonal melalui 4 tahapan yang lazim dilalui yaitu: (1) Perencanaan, (2) Pelaksanaan, (3) Pengamatan, dan (4) Refleksi. Berdasarkan hasil penelitian menunjukkan terdapat peningkatan skor rata-rata pre test 963 dan pada saat post test 1.084 atau meningkat 121 poin. Sehingga konseling teman sebaya meningkatkan keterampilan interpersonal siswa terbukti efektif. Guru bimbingan dan konseling disarankan dapat menerapkan konseling teman sebaya secara kontinyu dan bekerja sama dalam melakukan pembinaan dan pendampingan dalam meningkatkan kompetensi konselor sebaya.
\end{abstract}

Kata Kunci: Konseling Teman Sebaya; Komunikasi Interpersonal

\section{Pendahuluan}

Aktivitas yang sering dilakukan dalam kehidupan sehari hari oleh seseorang yakni berkomunikasi dengan orang lain. Komunikasi tersebut dapat terjadi baik dalam lingkungan keluarga, sekolah, maupun masyarakat. Dalam lingkungan keluarga interaksi dapat terjadi antara sesama anggota keluarga, baik orang tua dengan anak maupun sebaliknya. Dalam lingkungan sekolah interaksi dapat terjadi antara sesama warga sekolah yang ada dalam lingkungan sekolah tersebut. Dalam lingkungan masyarakat, interaksi seseorang akan meluas baik dengan teman akrab, teman sepermainan, dan orang dewasa lainnya tergantung sejauh mana individu mampu menempatkan diri.

Komunikasi dapat terjadi baik dalam bentuk verbal maupun nonverbal. Dalam bentuk verbal misalnya sekedar bertegur sapa, diskusi, wawancara, debat. Bentuk non verbal dapat berupa gerakan dari anggota tubuh, misalnya mendengarkan, mengangguk tanda setuju, sentuhan. Demikian pula ketika siswa memasuki lingkungan sekolah, ia akan melakukan komunikasi dengan teman-temannya. Komunikasi dalam bentuk verbal dapat dilakukan tegur sapa dengan teman-teman. Sedangkan dalam bentuk non verbal dapat dilakukan dengan merangkul teman atau melambaikan tangan ketika namanya dipanggil oleh temannya.

Siswa yang berada pada usia remaja, perlu untuk menjalin hubungan sosial yang baik dengan lingkungannya. Dalam masa remaja hal yang terpenting dan juga tersulit adalah penyesuaian diri dengan meningkatkannya pengaruh kelompok teman sebaya, perubahan dalam perilaku sosial, pengelompokan sosial yang baru, nilai-nilai baru dalam seleksi persahabatan, nilai-nilai baru dalam dukungan dan penolakan sosial, dan nilai-nilai baru dalam seleksi pemimpin [1]. Pada masa ini terdapat tiga proses sosial yang dilalui oleh remaja diantaranya berperilaku dapat diterima secara sosial, memainkan peran dilingkungan sosialnya, memiliki sikap positif terhadap kelompok sosialnya [2]. 
Berdasarkan pendapat Sulivan bahwa sahabat menjadi sangat penting untuk memenuhi kebutuhan sosialnya, karena pada usia remaja awal kebutuhan akan itimasi akan meningkat dan memotivasi remaja untuk mencari sahabat. Selanjutnya, sebuah penelitian terkait dengan perkembangan remaja mengungkapkan bahwa indeks prestasi teman-teman merupakan sebuah alat prediksi yang penting dari pencapaian positif di sekolah dan berkaitan dengan rendahnya perilaku negatif [3]. Dalam kaitannnya dengan keuntungan remaja memiliki kelompok teman sebaya yang positif. Penelitian [4] menerangkan bahwa kelompok teman sebaya sebagai kekuatan positif terbukti efektif dalam mempengaruhi perkembangan konsep diri remaja. Interaksi di antara teman sebaya dapat digunakan untuk membentuk teman bermain dan resensi serta solusi-solusi baru. Budaya teman sebaya yang positif memberikan kesempatan kepada remaja untuk menguji keefektifan komunikasi, tingkah laku, persepsi, dan nilai-nilai yang mereka miliki. Budaya teman sebaya yang positif sangat membantu remaja untuk memahami bahwa dia tidak sendirian dalam membantu menghadapi berbagai tantangan. Budaya teman sebaya yang positif dapat digunakan untuk membantu mengubah tingkah laku dan nilai-nilai remaja Laursen (dalam [5]). Salah satu upaya dalam membangun budaya teman sebaya yang positif adalah melalui konseling teman sebaya. Dalam hal ini [6] berpendapat bahwa "sosialisasi dan proses pembelajaran sosial memainkan peranan utama dalam membentuk perilaku dan sikap dari orang-orang muda. Melalui sosialisasi dalam budaya, individu memperoleh pandangan mengenai sifat dunia sosial, mengembangkan serangkaian nilai-nilai dan memahami makna kegiatan dalam komunitas mereka".

Kelompok pertemuan (encounter group) yang dikembangkan oleh Rogers merupakan suatu sarana di mana seseorang dapat berbicara menembus halangan yang dibangun oleh mereka sendiri dan orang lain dengan maksud mereka dapat bereaksi secara terbuka dan bebas satu sama lain. Fokusnya terletak pada proses dan dinamika interaksi pribadi yang langsung, kelompok tersebut terdiri dari 8 sampai 18 orang. Para anggota dapat menentukan arah dan tujuannya, akan tetapi dengan masukan kognitif yang diberikan oleh seorang pemimpin yang bertanggungjawab memfasilitasi pemikiran maupun perasaan anggotanya [7]. Adapun nilai yang diintegrasikan ke dalam layanan konseling teman sebaya respek, kebebasan dan tanggungjawab, kebermaknaan, disiplin menghargai waktu [8].

Penerapan nilai-nilai persahabatan penting dalam suasana konseling teman sebaya, mengingat terdapat kelebihan yang akan diperoleh dari penerapan nilai-nilai tersebut. Diantaranya siswa akan memiliki rasa kepedulian (respect) baik terhadap dirinya maupun dengan orang lain. Ketika siswa memiliki rasa menghargai maka akan memunculkan nilai kebermaknaan akan kehadiran dirinya di suatu tempat. Pada akhirnya akan memunculkan nilai kebebasan yang bertanggungjawab bahwa dirinya terikat akan norma-norma yang ada di sekitarnya. Teman sebaya dianggap sebagai orang yang mau mengerti dan paling peduli terhadap permasalahan yang sedang dihadapi tanpa harus menggurui atau memarahi. Teman sebaya juga dianggap sahabat curhat yang yang paling aman, mereka punya bahasa yang sama dalam berkomunikasi sehingga dapat menyampaikan masalahnya dan tidak harus belajar bagaimana bicara yang sopan, resmi seperti hendak berbicara dengan guru.

Konseling teman sebaya di SMA Negeri 1 Segedong sudah pernah dilaksanakan namun belum maksimal, tidak mengandung muatan keterampilan interpersonal . Atas dasar tersebut, maka peneliti tertarik untuk melakukan penelitian mengenai "Meningkatkan Keterampilan Interpersonal melalui Konseling Teman Sebaya Siswa SMA Negeri 1 Segedong.

\section{Metode}

Penelitian ini menggunakan metode penelitian tindakan bimbingan dan konseling (PTBK). Prosedur penelitian tindakan bimbingan dan konseling menurut [9]. Model bagan penelitian tindakan secara garis besar terdapat 4 tahapan yang lazim dilalui yaitu: (1) Perencanaan, (2) Pelaksanaan, (3) Pengamatan, dan (4) Refleksi.

Penelitian tindakan bimbingan dan konseling ini dilaksanakan pada bulan Oktober 2016 bertempat di SMA Negeri 1 Segedong dengan subjek penelitian yaitu 34 orang siswa. Metode pengumpulan datanya menggunakan studi dokumentasi, observasi, wawancara, dan angket yang selanjutnya dilakukan triangulasi sumber untuk menggali kebenaran informasi melalui sumber perolehan data yang berbeda.

Teknik analisa data dalam penelitian ini menggunakan analisis data kuantitatif dan kualitatif dengan langkahlangkahnya berupa pengumpulan dan penafsiran data serta penyimpulan hasil perolehan data penelitian.

\section{HASIL DAN PEMBAHASAN}

\section{A. Hasil}

Berdasarkan hasil penelitian, diketahui bahwa konseling teman sebaya pernah dilaksanakan di SMA Negeri 1 Segedong, pelaksanaan kegiatan tersebut bekerjasama dengan pihak Puskesmas. namun pihak sekolah tidak terlibat secara penuh. Pihak sekolah dalam hal ini guru bimbingan dan konseling hanya mempersiapkan calon konselor sebaya. Karena bersifat kerjasama maka sekolah hanya menunggu pemberitahuan dari pihak Puskesmas sehingga dari sisi perencanaan, pelaksanaan maupun evaluasi tidak dapat dilaksanakan oleh pihak sekolah. Beberapa hambatan yang ditemui adalah kurangnya sarana dan prasarana untuk mengadakan pelatihan konseling teman sebaya seperti ruangan, waktu yang disediakan terbatas yakni 30 menit, untuk setiap kelas. Selain itu, faktor penghambat lainnya adalah kurangnya pengetahuan siswa dan guru BK akan konseling teman sebaya yang ideal.

Hasil studi pendahuluan yang dilakukan pada siswa SMA Negeri 1 Segedong dengan responden 175 siswa menunjukkan bahwa jumlah atau frekuensi tingkat keterampilan interpersonal rendah adalah 34 siswa (19.4\%) 
dan siswa yang memiliki keterampilan interpersonal tinggi terdapat 141 siswa (80.6\%). Untuk mempermudah melihat secara visual keterampilan interpersonal siswa SMA Negeri 1 Segedong, peneliti menyajikan dalam bentuk tabel berikut.

TABEL I

KATEGORI KETERAMPILAN INTERPERSONAL SISWA

\begin{tabular}{ccc}
\hline KATEGORI & F & \% \\
\hline Sangat Tinggi & - & - \\
Tinggi & 141 & 80,6 \\
Rendah & 34 & 19,4 \\
Sangat Rendah & - & - \\
\hline JUMLAH & 175 & 100
\end{tabular}

Dari tabel di atas menunjukan bahwa jumlah siswa yang memiliki keterampilan interpersonal rendah adalah 34 siswa $(19.4 \%)$ dan siswa yang memiliki keterampilan interpersonal tinggi terdapat 141 siswa (80.6\%). Untuk mempermudah melihat secara visual keterampilan interpersonal siswa SMA Negeri 1 Segedong, peneliti menyajikan dalam bentuk gambar berikut.

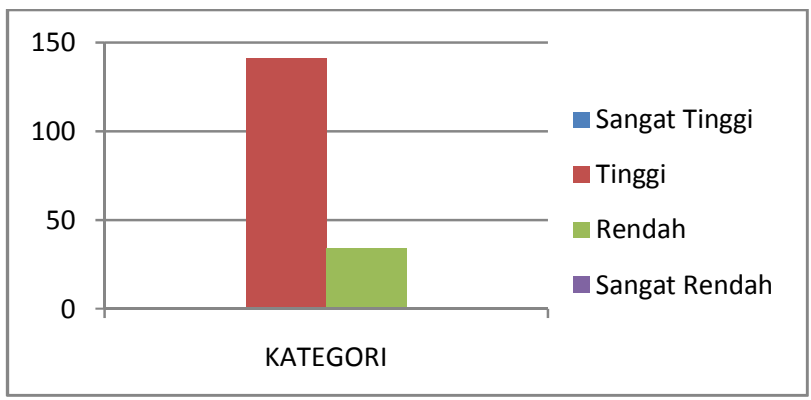

Gambar 1 Tingkat Keterampilan Interpersonal SMA Negeri 1 Segedong

Karakterisitk yang diungkap melalui skala keterampilan interpersonal terdiri dari lima aspek yaitu; (1) keterampilan membuka diri, (2) keterampilan mempengaruhi, (3) keterampilan mengekspresikan perasaan verbal dan non verbal, (4) keterampilan mendengarkan dan menanggapi, dan (5) keterampilan berinteraksi dan bekerja dalam kelompok. Berikut sajian dalam bentuk tabel tingkat keterampilan interpersonal siswa SMA Negeri 1 Segedong sebagai berikut.
TABEL II

SEBARAN TINGKAT KETERAMPILAN INTERPERSONAL SISWA BERDASARKAN INDIKATOR

\begin{tabular}{|c|c|c|c|c|c|c|c|}
\hline \multirow[t]{2}{*}{ No } & \multirow[t]{2}{*}{ Indikator } & \multicolumn{2}{|l|}{$\mathbf{F}$} & \multicolumn{3}{|c|}{ Kategori } & \\
\hline & & $\%$ & ST & $\mathbf{T}$ & $\mathbf{R}$ & SR & \\
\hline \multirow[t]{2}{*}{1} & \multirow[b]{2}{*}{$\begin{array}{l}\text { Keterampilan } \\
\text { membuka diri }\end{array}$} & $\mathrm{F}$ & & 122 & 53 & - & 175 \\
\hline & & $\%$ & & 70 & 30 & - & $\begin{array}{c}100 \\
\%\end{array}$ \\
\hline \multirow[t]{2}{*}{2} & \multirow{2}{*}{$\begin{array}{l}\text { Keterampilan } \\
\text { mempengaruhi }\end{array}$} & $\mathrm{F}$ & - & 132 & 43 & - & 175 \\
\hline & & $\%$ & - & 75 & 25 & - & $\begin{array}{c}100 \\
\%\end{array}$ \\
\hline \multirow[t]{2}{*}{3} & Keterampilan & $\mathrm{F}$ & - & 116 & 59 & - & 175 \\
\hline & $\begin{array}{l}\text { mengekspresikan } \\
\text { perasaan verbal } \\
\text { dan non verbal }\end{array}$ & $\%$ & - & 66.3 & 33,7 & - & $\begin{array}{c}100 \\
\%\end{array}$ \\
\hline \multirow[t]{2}{*}{4} & Keterampilan & $\mathrm{F}$ & - & 124 & 51 & - & 175 \\
\hline & $\begin{array}{l}\text { mendengarkan dan } \\
\text { menanggapi }\end{array}$ & $\%$ & - & 70.8 & 29.2 & - & $\begin{array}{c}100 \\
\%\end{array}$ \\
\hline \multirow[t]{5}{*}{5} & Keterampilan & $\mathrm{F}$ & - & 105 & 30 & 40 & 175 \\
\hline & $\begin{array}{l}\text { berinteraksi dan } \\
\text { bekerja dalam } \\
\text { kelompok }\end{array}$ & $\%$ & - & 60 & 17 & 23 & $\begin{array}{c}100 \\
\%\end{array}$ \\
\hline & Rata-Rata & $\mathrm{F}$ & & 424 & 236 & 40 & 700 \\
\hline & & $\%$ & & 60.5 & 33.71 & 5.71 & 100 \\
\hline & & & & 7 & & & $\%$ \\
\hline
\end{tabular}

Tabel II memperkuat asumsi dasar bahwasanya masih terdapat siswa dengan tingkat keterampilan interpersonal yang rendah. Artinya data hasil skala keterampilan interpersonal tersebut selaras dengan permasalahan yang selama ini terjadi pada siswa. Melihat data pada tabel II menunjukkan bahwa perlu adanya upaya bantuan bagi siswa agar mereka dapat mengatasi masalah dalam kehidupan sosial yang layak. Pelaksanaan konseling teman sebaya saja tidak cukup untuk mengatasi masalah keterampilan interpersonal. Guru Bimbingan dan Konseling membutuhkan cara yang tepat dan efektif untuk dapat membantu meningkatkan keterampilan interpersonal siswa yang rendah.

Siklus I

1. Perencanaan Tindakan

Tindakan pada siklus I direncanakan selama dua pertemuan. Pertemuan dilakukan siang hari di ruang perpustakaan dan dilaksanakan di sela jam pelajaran. Peneliti menetapkan analisa kebutuhan yaitu identifikasi penyebab rendahnya keterampilan interpersonal siswa.

2. Pelaksanaan Tindakan

Peneliti melakukan pemilihan calon konselor sebaya di SMA Negeri 1 Segedong, dengan karakteristik sebagai berikut: memiliki minat untuk membantu, dapat diterima orang lain, toleran terhadap perbedaan sistem nilai, energik, secara sukarela bersedia membantu orang lain, memiliki emosi yang stabil dan memiliki prestasi belajar yang cukup baik atau minimal rerata, serta mampu menjaga rahasia, memiliki keterampilan interpersonal dengan kategori tinggi, memahami norma sosial, hukum dan agama. Pemilihan calon konselor sebaya, dilakukan dengan berkoordinasi dengan guru BK. 


\section{Observasi}

Pada hasil pengamatan siklus I masih dijumpai peserta yang kurang antusias dan kurang aktif dalam kegiatan, maka pada siklus ke II diharapkan sudah cenderung lebih leluasa dalam mengikuti konseling teman sebaya.

\section{Refleksi}

Dari hasil observasi oleh pengamat dan catatan peneliti diperoleh hal-hal sebagai berikut:

a. Konselor sebaya sudah mulai terbiasa untuk menciptakan suasana konseling teman sebaya yang berfokus pada anggota sebaya dalam pemecahan masalah.

b. Sebagian peserta konseling sebaya telah cukup terbiasa dengan kondisi tersebut dalam pemecahan masalah bersama dalam dinamika kelompok. Hal ini dapat dilihat dari hasil observasi terhadap aktifitas peserta konseling sebaya yang tergolong cukup berhasil.

c. Masih ada peserta konseling sebaya yang belum dapat menghilangkan resistansi terhadap peseta konseling sebaya sehingga kurang terlibat aktif dan kurang inisiatif dalam kegiatan konseling.

Siklus II

1. Perencanaan Tindakan

Pertemuan siklus II direncanakan 2 kali pertemuan dan konseling sebaya dilakukan pada pagi hari. Rencana tindakan pada siklus II pada dasarnya sama dengan siklus I, hanya ada perbedaan yaitu pelaksanaan konseling teman sebaya dirubah dari siang hari dilaksanakan pagi hari.

2. Pelaksanaan Tindakan

Pelaksanaan tindakan pada siklus ke II merupakan realisasi dari rencana yang sudah disusun dan dapat dilakukan dengan baik. Konselor sebaya melaksanakan konseling sesuai dengan yang di ajarkan oleh peneliti dalam rangka meningkatkan keterampilan interpersonal siswa.

3. Observasi

Dari hasil pengamatan yang dilakukan pada siklus I masih dijumpai anak yang kurang antusias dan kurang aktif dalam kegiatan, pada siklus II ini sudah tidak ada. Dari hasil pengamatan siswa, siswa sudah antusias dan termotivasi dalam mengikuti kegiatan konseling teman sebaya secara keseluruhan.

4. Refleksi

Berdasarkan hasil observasi oleh pengamat dan catatan peneliti diperoleh data sebagai berikut: Keberhasilan konselor sebaya, yaitu: pada siklus II konselor sebaya keterampilan membuka diri, keterampilan mempengaruhi, keterampialn mengekspresikan perasaan verbal dan non verbal, keterampilan mendengarkan dan menanggapi serta keterampilan berinteraksi dan bekerja sama dalam kelompok. Hal ini disebab kan oleh kesetaraan yang dimiliki oleh siswa yang merasa sama dan tidak ada perbedaan satu sama lainnya.

Secara kuantitatif keterampilan interpersonal siswa dapat dilihat dari perbandingan nilai evaluasi awal dan nilai evaluasi akhir yang diperoleh siswa dari 34 siswa yang diberikan bantuan oleh konselor sebaya terjadi peningkatan skor keterampilan interpersonal siswa sebagai berikut.
TABEL III

DATA SKOR RATA-RATA KETERAMPILAN INTERPERSONAL SISWA

\begin{tabular}{lccc}
\hline Keterangan & $\begin{array}{c}\text { Pre } \\
\text { Tes }\end{array}$ & $\begin{array}{c}\text { Post } \\
\text { Test }\end{array}$ & Peningkatan \\
\hline $\begin{array}{l}\text { Keterampilan } \\
\text { Interpersonal }\end{array}$ & 963 & 1.084 & 121 \\
\hline
\end{tabular}

Agar lebih jelas sebaran peningkatan pada setiap indikator dapat dilihat pada gambar sebagai berikut.

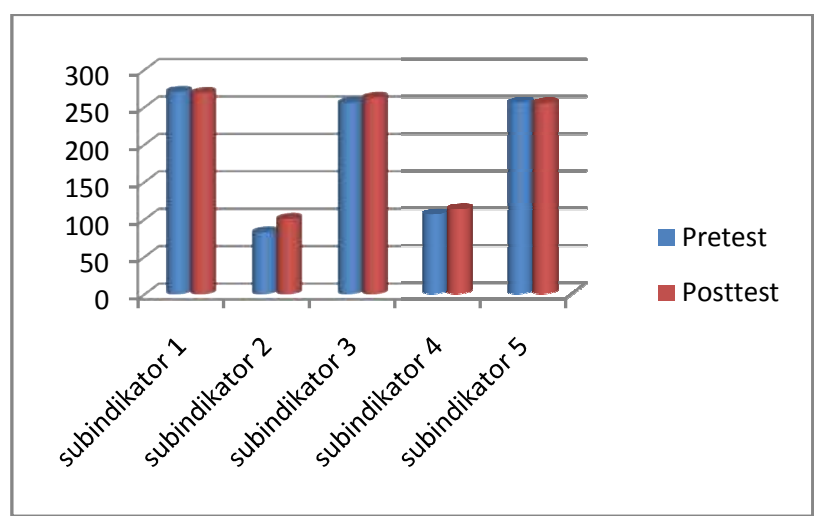

Gambar 2 Histogram Peningkatan Skor Perindikator

Berdasarkan tabel diatas menunjukkan bahwa siswa yang memiliki keterampilan interpersonal yang rendah setelah diberi perlakuan oleh konselor sebaya memiliki peningkatan skor keterampilan interpersonal. Terjadinya peningkatan ini dikarenakan adanya pengaruh budaya teman sebaya yang saling memberikan pengaruh satu sama lain, pengaruh tersebut dapat berupa sikap positif siswa terhadap kelompok sosialnya.

\section{B. Pembahasan}

Berdasarkan analisis data di atas, menunjukan bahwa ada peningkatan keterampilan interpersonal siswa antara sebelum dan sesudah mendapatakan layanan konseling teman sebaya. Hasil penelitian menunjukan bahwa rata-rata keterampilan interpersonal siswa setelah mengikuti kegiatan konseling teman sebaya mengalami peningkatan. Dengan demikian dapat disimpulkan bahwa keterampilan interpersonal siswa sebelum diberikan konseling teman sebaya dengan sesudah diberikan ada perbedaan dan mengalami peningkatan yang signifikan.

Konseling teman sebaya efektif dalam meningkatkan keterampilan interpersonal siswa karena melalui kegiatan konseling teman sebaya, teman yang dibantu akan diajak untuk saling berinteraksi baik secara individual maupun kelompok dalam membahas masalah terkait keterampilan interpersonal. Terbukti pada proses pelaksanaan, teman yang dibantu merasa lebih nyaman mengungkapkan masalahnya tanpa ragu dan takut dibantu oleh teman sebayanya sendiri. Selain itu, semakin sering siswa yang dibantu berkumpul dan berinteraksi dengan konselor sebaya maka akan terjadi pertukaran peer culture antar sebaya. 
Adanya dinamika dan pengaruh dalam kelompok sebaya, individu dapat merumuskan dan memperbaiki konsep diri, menguji dirinya sendiri dan orang lain melalui kelompok yang dimiliki dan dibentuk oleh individu tersebut. Kegiatan konseling teman sebaya yang dilaksanakan dalam penelitian ini, tidak hanya dilakukan secara individual tetapi juga secara kelompok dengan tujuan untuk meningkatkan keterampilan interpersonal siswa. Selain itu, pemanfaatan teman sebaya untuk menjalankan kegiatan konseling teman sebaya ini, akan mendatangkan keleluasaan dalam berinteraksi dan memunculkan kehidupan kelompok yang interaktif dan dinamis serta menjalin hubungan yang lebih akrab dengan teman-temannya.

Dengan demikian mereka akan mendapatkan dukungan dan termotivasi melalui wadah konseling teman sebaya dan diskusi kelompok yang hangat, akrab, dinamis dan interaktif dengan memberikan warna yang kompetitif secara positif dalam mencapai tujuan yang diinginkannya, seperti kebutuhan untuk menyesuaikan diri dengan teman-teman sebayanya dan diterima oleh mereka, kebutuhan untuk bertukar pikiran dan berbagi perasaan, kebutuhan menemukan nilai-nilai kehidupan sebagai pegangan, dan kebutuhan untuk menjadi mandiri.

\section{KESIMPULAN}

Konseling teman sebaya sudah dilaksanakan di SMA Negeri 1 Segedong dengan melewati 3 (tiga) tahapan, yakni tahap pemilihan, tahap pelatihan, dan tahap pengorganisasian. Pelaksanaan kegiatan tersebut melibatkan pihak luar. Sekolah hanya menyediakan calon konselor sebaya. Sehingga guru BK tidak dilibatkan dalam pelatihan. Pelatihan hanya berfokus pada materi bukan pada keterampilan dalam memberi bantuan. Dengan demikian guru BK tidak dapat melaksanakan secara mandiri.

Berdasarkan hasil penelitian tersebut maka siklus ke II dari hasil pengamatan terdapat peningkatan yang signifikan yaitu siswa yang keterampilan interpersonal pada saat dilakukan pre test 963 dan skor rata-rata pada post test keterampilan interpersonal siswa 1.084 mengalami peningkatan 121 poin. Berdasarkan hasil data tersebut dapat disimpulkan konseling teman sebaya dapat meningkatkan keterampilan interpersonal siswa.

\section{DAFTAR PUSTAKA}

[1] Juntika, A. N., \& Agustin, M. (2011). Dinamika Perkembangan Anak dan Remaja. Bandung: PT. Refika Utama.

[2] Hurlock, E. B. (2002). Psikologi Perkembangan; Suatu Pendekatan Sepanjang Rentang Kehidupan. Jakarta: Penerbit Erlangga.

[3] Santrock, J.W. (2012). Life-Span Development: Perkembangan Masa Hidup. Edisi ketiga belas. Jakarta:Penerbit Erlangga.

[4] Aihie, N.O., \& Egbochuku, E.O. (2009). Peer group counselling and school influence on adolescents' self-concept. Journal of Instructional Psychology, 36, 1.

[5] Suwarjo. (2008). Konseling Teman Sebaya Untuk Pengembangan Daya Lentur (Resilience) Remaja. Makalah Disampaikan pada Seminar Pendidikan di UNY.

[6] Cowie, H. \& Wallace, P. (2000). Peer Support in Action: From Bystanding to Standing By. London: Sage Publications.

[7] Graham, H. (2005). Psikologi . Bandung: Pustaka Pelajar.

[8] Corey, G. (1995). Teori dan Praktek dari Konseling dan Psikoterapi. Edisi Empat. Jakarta: IKIP Semarang Press.

[9] Hidayat, D.R., \& Aip, B. (2012). Penelitian Tindakan dalam Bimbingan Konseling. Jakarta: Indeks. 